\title{
Human stickiness as a counterforce to brain drain: Purpose-driven behaviour among Tanzanian medical doctors and implications for policy
}

Ndikumana

David Emmanuel ${ }^{1,2}$, Maria Elo ${ }^{3,4,5}$ and Rebecca Piekkari ${ }^{6}$

${ }^{1}$ School of Public Administration and Management, Mzumbe University, Mzumbe, Tanzania; ${ }^{2}$ Adger University, Kristiansand, Norway; ${ }^{3}$ Department of Marketing and Management, University of Southern Denmark, Odense, Denmark; ${ }^{4}$ Belt and Road Institute of International Business, School of Economics, Shanghai University, Shanghai, China; ${ }^{5}$ Turku School of Economics, University of Turku, Turku, Finland; ${ }^{6}$ Department of Management Studies, School of Business, Aalto University, Espoo, Finland

Correspondence:

R Piekkari, Department of Management Studies, School of Business, Aalto University, Espoo, Finland

e-mail: rebecca.piekkari@aalto.fi
Received: 14 September 2018

Revised: 9 July 2019

Accepted: 30 August 2019

Online publication date: 4 November 2019

\begin{abstract}
We explain why a group of Tanzanian medical doctors decided to stay in their home country despite a massive brain drain and pressure to migrate. We argue that purpose-driven behaviour among medical doctors serves as a counterforce to brain drain, fostering human stickiness in a developing country context. A sense of purpose provides a novel lens to understand voluntary non-migration of highly-skilled professionals under extreme conditions. Furthermore, incoming expatriate doctors build local capacity by sharing skills and expertise with Tanzanian doctors. This affects the medical doctors' motives to migrate, further reducing brain drain. These individual-level decisions not to migrate find their application in policy. We advocate policies that support purpose-driven behaviour and generate long-term commitment to a location, while advancing short-term mobility for knowledge sharing. The policy initiatives are targeted at actors in the sending and receiving countries as well as in international organisations, covering concerted multi-layered policies to support family and community embeddedness, to facilitate the incoming of expatriate doctors and foreign exchange, and to cultivate benefits of circular migration. We argue that migration behaviour is more individually grounded and socio-emotionally constructed than what dominant economic-based explanations suggest.

Journal of International Business Policy (2019) 2, 314-332.
\end{abstract}

https://doi.org/ | 0.1057/s422 I4-019-00036-7

Keywords: migration policy; brain drain; medical doctors; purpose; faith; stickiness; Tanzania

The online version of this article is available Open Access

\section{INTRODUCTION}

This study addresses individual-level motivations of medical doctors to stay in Tanzania, one of the countries in Sub-Saharan Africa that has the lowest level of medical doctors per capita in the world (Kwesigabo et al., 2012). Brain drain is a typical problem in developing countries (e.g. Adams, 2003; Beine, Docquier, \& Rapoport, 2008) and a particularly acute concern in the African health care sector (Hagopian, Thompson, Fordyce, Johnson, \& Hart, 2004), where the ratio of the highly educated talent that 
leaves versus stays in the country is alarming (Adams, 2003; Emmanuel, 2018; WHO, 2014). As part of a global workforce of highly skilled professionals, medical doctors are increasingly mobile due to attractiveness of global careers (Habti \& Elo, 2018). Therefore, retaining and attracting talent represents a core concern for developing countries (OECD, 2015; UNESCO, 2018).

In contemporary migration and labour diaspora research, the dominant explanatory mechanism of migration flows is still the framework of push and pull forces (Cohen, 2008; Dorigo \& Tobler, 1983; Elo \& Minto-Coy, 2018; Moullan, 2018; Spencer, 2011; Zimmermann, 1996). These forces capture economic reasons to migrate from the sending to the receiving country (Adams, 2003; Castles, De Haas, \& Miller, 2013). However, individuals respond differently to push and pull forces. Furthermore, there is a wide gulf between the agency of highly-skilled professionals whether or not to migrate (Carling \& Schewel, 2018), and the fragmented, multi-layered policy-making that regulates the competition for talent (e.g. Beechler \& Woodward, 2009; Cerna, 2016). Previous research has often adopted a policy-by-policy approach (see Spencer, 2004, 2011), downplaying the connections between different policies and policy actors, which is necessary to shed light on migratory behaviour. Moreover, migration ${ }^{1}$ research implicitly assumes that individuals in less developed countries contemplate leaving their home country (Carling \& Schewel, 2018; Elo \& Minto-Coy, 2018; Otrachshenko \& Popova, 2014) and that there are expected economic benefits associated with migration (Alleyne \& Solan, 2019). As a result, migration research has been less focused on the reasons that keep local talent in the home country and prevent them from migrating.

Hence, the aim of this qualitative study is to understand human stickiness as a counterforce of migration and propose policy initiatives from a bottom-up perspective to encourage talent retention and attraction in a developing country context. We explain the atypical behaviour of a group of Tanzanian medical doctors who decided to stay in their home country despite extremely difficult local circumstances, the departure of their colleagues, and the lures of a better future abroad. This atypical case is theoretically interesting (Aharoni, 2011), because it suggests that migration cannot be explained by macro-level economic factors alone. We selected Tanzania because it suffers from the lowest level of medical doctors per capita in the world (Kwesigabo et al., 2012) and this ratio has hardly improved during the past few years (MoHSW, 2012; WHO, 2014). This paper addresses how individual-level decisions of voluntary nonmigration (Tjadens, Weilandt, \& Eckert, 2013) find application in national and global migration policy and poses two research questions: Why do highlyskilled professionals decide to stay in and not leave their country of origin? What implications can be drawn for policy-makers in the affected countries and in international organisations?

We offer two contributions to migration research. First, contrary to economic reasoning, we found that the Tanzanian medical doctors we interviewed had a strong sense of purpose in life, which influenced their migratory behaviour and kept them in their home country. Their purposedriven behaviour resulted in human stickiness that served as a counterforce to reduce brain drain from Tanzania. We argue that purpose-driven behaviour may fill a void caused by regulatory deficiencies in human resource governance and migration policy, preventing highly-skilled professionals from leaving. Previous research has identified economicbased motivations of migration (e.g. Kultalahti, Karppi, \& Rantala, 2006; see also Hatton \& Williamson, 2005), but rarely related purpose-driven individual behaviour to migration, especially that which is faith-based (for an exception, see Marchal $\&$ Kegels, 2003). This lacuna applies also to management research more broadly (Anderson, Quinn, \& Thakor, 2018; Barnard, Cuervo-Cazurra, \& Manning, 2017). We join the stream of research suggesting that migration behaviour is more individually grounded and socio-emotionally constructed than what economic-based explanations suggest (Barnard \& Pendock, 2013; Boccagni \& Baldassar, 2015). Thus, purpose-driven individual behaviour offers a novel lens to better understand human stickiness of migratory behaviour.

Second, we offer policy initiatives for keeping highly-skilled professionals in their country of origin. The deep family and social embeddedness of the Tanzanian medical doctors suggests that policies supporting children's education, spousal appointments and recruitment of other family members would be beneficial for retaining highlyskilled professionals. Furthermore, due to the embeddedness of these doctors in the global workforce, policies facilitating the incoming of expatriate doctors can also enhance local talent retention. Expatriate doctors, who come on short-term assignments, share their knowledge and expertise 
through collaborative work and research with Tanzanian medical doctors. Our findings show that the incoming flow of foreign experts is a powerful means to develop professional competence and build capacity locally in Tanzania. We argue that the interrelatedness between local talent retention and international circular migration has received inadequate attention to date.

The rest of the paper is organised as follows. We first analyse the broader literature on (non-)migration decisions of highly-skilled professionals, emphasising economic-based explanations of global people flows. We then turn to research on migration behaviour of medical doctors in Africa. This stream of literature stands out, because, unlike much of the migration research to date, it has identified purpose-driven behaviour and human stickiness. We conclude the review by defining the notion of sense of purpose. Thereafter, we present the design of a qualitative case study about why a group of Tanzanian medical doctors decided to stay in their country of origin despite strong pressure to migrate. Based on the findings, we propose implications for policy and discuss avenues for future research.

\section{LITERATURE REVIEW}

\section{Policies and Forces Shaping Migration}

The question of why some highly-skilled professionals decide to stay in their country of origin and voluntarily not migrate from a developing country is intriguing (e.g. Carling \& Schewel, 2018; De Haas, 2010). A common explanation is that potential migrants respond differently to a combination of migration policies and various push and pull forces (e.g. Kultalahti et al., 2006; Moullan, 2018). Migration policies ${ }^{2}$ pull migrant resources and talent from developing ('sending') to developed ('receiving') countries (Adams, 2003; Tjadens et al., 2013). Typically, national policy actors regulating international in-migration carefully select ${ }^{3}$ the right type of human resources needed and design suitable policies to obtain them. However, global policy actors do not necessarily consider the detrimental effect of brain drain of highly skilled professionals on sending countries (e.g. Czaika, 2018; De Haas, 2010; Moullan, 2018; Tjadens et al., 2013; UNESCO, 2018). Consequently, the promise of triple win via triangular human talent flow does not materialise, further contributing to extreme conditions in developing countries (cf. Barnard et al., 2017; Tung, 2008). This highlights some of the challenges associated with current policies.

Developing countries also use migration policy to reduce out-migration. However, these restrictive policies violate the freedom to out-migrate, stimulate aspirations for emigration, and diminish local stickiness and attractiveness (Kultalahti et al., 2006; Zimmermann, 1996). In this regard, restrictive policies can be a double-edged sword if not combined with supporting incentives. Opportunities for career building, well-being, and professional development at home are typical incentives (e.g. Glick Schiller \& Salazar, 2013) that reduce drivers of migration in the first place (Carling \& Collins, 2018).

The underlying assumption in much of the existing research is that the outcome of migration - life per se - is better after migration and that the migratory benefits are individual (e.g. Peters, Chakraborty, Mahapatra, \& Steinhardt, 2010). The promise of a better life is particularly attractive for medical doctors from developing countries (Clemens \& Pettersson, 2008). The individual can incur positive effects in the post-migration host context, or these benefits can be realised upon return and through many forms, such as social or financial remittances (e.g. Riddle \& Brinkerhoff, 2011). Alleyne and Solan (2019) address the effects of diaspora networks attracting migrants and the expected 'diaspora dividends' that migrants realise upon return. This suggests that there are multiple recipients of the benefits, not only those who migrate (see Vaaler, 2013).

Contemporary highly-skilled professionals may behave like free agents, because they are less subject to regime control and state intervention than previously (e.g. Cohen, 2008; Habti \& Elo, 2018; Kultalahti et al., 2006). These professionals assess diverse push and pull forces as drivers of migration (Moullan, 2018; see also push-pull plus theory, Van Hear, Bakewell, \& Long, 2018) and weigh long-term benefits against disadvantages, while at the same time having multiple options of staying (Bakewell, 2010). Carling and Schewel (2018) propose a twostep migration model that distinguishes between aspiration versus ability to migrate, the latter being strongly related to migration policy and available options. Hence, we understand migration as an outcome of a complex and multi-layered interplay of factors that explains individuals' decision (not) to migrate (Bakewell, 2010; De Haas, 2010; Tjadens et al., 2013). 
Previous research is dominated by the rational, economic-based push and pull approach (e.g. Lee, 1966). However, recent research on boundaryless careers and mobility of highly-skilled professionals shows that numerous career and personal development paths influence migratory decision-making, highlighting individual agency in a more nuanced way (e.g. Czaika, 2018; Habti \& Elo, 2018; Stahl, Miller, \& Tung, 2002). Cerdin, Diné and Brewster (2014) undertook a qualitative study of highlyskilled migrants in France and developed a typology to explain their motivation to migrate. They argue that potential migrants assess the expected gains, losses and the associated risk in their decision-making. Based on an international cross-country study, Tjadens et al. (2013) add stick (premigration) and stay (post-migration) factors to the traditional list of push and pull factors. ${ }^{4}$ Stick factors, that keep the person from migrating, are associated with personal or social aspects of life, and are becoming increasingly important on a global scale.

Migration decisions are not made in vacuum but embedded in various layers of context (e.g. family and networks) and intertwined with emotions and bounded rationality (e.g. Boccagni \& Baldassar, 2015; Elo \& Vemuri, 2016; Lerner, Li, Valdesolo, \& Kassam, 2015; Tjadens et al., 2013). The decision to stay can take place in either pre- or post-migration stages, but we are concerned with the pre-migration stage. The group of voluntary non-migrants with aspirations to stay is theoretically interesting, because of the notable drivers of migration in a developing country context (Carling \& Collins, 2018; Carling \& Schewel, 2018; Schewel, 2015).

Thus, migration research explains migratory decision-making primarily based on economic considerations, while the literature on (non-)migration of medical professionals in Africa provides an alternative explanation.

\section{Migration Decisions of Medical Professionals in Africa}

Our reading of research on medical professionals in Africa suggests that a sense of purpose may explain why health workers are motivated to continue working in developing countries despite highly disadvantageous and extreme conditions. A study of Tanzania finds that the major reasons for dissatisfaction and considerations to resign or migrate were related to low salaries or rewards, problems in the working environment and inadequate facilities to perform expected tasks (Leshabari, Muhondwa,
Mwangu, \& Mbembati, 2008). Interestingly, at the same time, $56 \%$ of the health care workers claimed that they were motivated to work in the hospital in order to serve people (Leshabari et al., 2008). Similar findings were arrived at in a study of medical doctors' work motivation in Kenya (Mbindyo, Gilson, Blaauw, \& English, 2009). Serneels et al. (2010) found that African medical students with a religious faith, especially from rural areas, were particularly motivated to help the sick and the poor. Also, health workers in Ethiopia and Ruanda from rural areas and Adventists were significantly more willing to work under extreme conditions in rural areas than others (Serneels et al., 2010). While dissatisfaction with work, income, and lack of motivation have been proposed as possible explanations for migration (e.g. Peters et al., 2010), the findings from Africa suggest an alternative explanation. They point to religious faith as a potential reason behind individuals' purpose-driven behaviour in specific contexts (Ojo, 2015; Serneels et al., 2010).

Earlier work on Africa has identified the importance of a bigger purpose in life (Jackson \& Coursey, 1988; Ojo, 2015). Ties with members of the family, friends, clans and tribes are part of the social fabric that generates social embeddedness and collectivity (Barnard et al., 2017; Radcliffe-Brown \& Forde, 2015). These layers of context influence migratory behaviour (Spencer, 2011; Spencer \& Charsley, 2016). Community-based relationships and social norms, such as Ubuntu and Kgotla (Barnard et al., 2017), shift the attention from economic to noneconomic factors in explaining non-migration. The broader psychological literature has identified a sense of purpose, typically among missionary workers, medical doctors and employees working for NGOs, as their work is particularly challenging or ideologically driven (e.g. Wrzesniewski, McCauley, Rozin, \& Schwartz, 1997).

\section{Sense of Purpose and Purpose-Driven Behaviour} In this paper, we regard purpose as an individuallevel umbrella concept that refers to a set of noneconomic, emotional and life-philosophical considerations influencing individual migratory behaviour and producing long-term commitment to a location. Purpose has also been defined as a 'central, self-organizing life aim' that shapes a person's identity and provides a framework for understanding this person's goals and behavioural patterns in everyday life (Kashdan \& McKnight, 2009: 303). Purpose refers to the broader meaning in life in 
terms of helping others or making the world a better place (Csikszentmihalyi, 2004). It has an inherently social, interpersonal and embedded characteristics (Lerner et al., 2015). Baumgarten (2013: 15) integrates 'purpose at work with the purpose in life' which comes close to the meaning of the term 'calling'. People with callings do not work for financial gain or career advancement, 'but instead for the fulfillment' that the work brings to them; their work is 'seen as socially valuable - an end in itself' (Wrzesniewski et al., 1997: 22).

In developing countries where economic drivers to stay or return later are limited or non-existent, staying can be considered altruistic behaviour, i.e. doing good and giving back. Migrants experience the emotional pain of migrating when moving away from family and friends, because it involves a fundamental change affecting all parties involved. 'These [stick factors] are the psychological costs, not counting the stresses associated with the travel into the unknown and trying to find one's balance abroad' (Tjadens et al., 2013: 21). Previous research conceptualises altruistic behaviour as post-migratory and associates it with returnees' concerns about the well-being and development of the 'homeland' (Brinkerhoff, 2009; Nielsen \& Riddle, 2009; Riddle \& Brinkerhoff, 2011). Migration may indeed be motivated by a purpose to alleviate poverty or provide medical support as evidenced by many employees of international and charity organisations (Akintola, 2010). Expatriate doctors, who come from the developed world to Africa on short-term contracts, are often highly motivated by a purpose to contribute locally. To date, research on altruistic behaviour has focused on diasporic returnee impact and benefits, such as establishing businesses, creating jobs or sponsoring community (e.g. Brinkerhoff, 2009; Elo, 2016; Elo \& Riddle, 2016; Minto-Coy \& Elo, 2017; Nielsen \& Riddle, 2009; Nkongolo-Bakenda \& Chrysostome, 2013; Siddiqui \& Tejada, 2014; Vaaler, 2011).

In this paper, we focus on purpose-driven behaviour of voluntary non-migrants whose behaviour is seen as a socially constructed, multi-layered and context-specific force that produces human stickiness locally. We define human stickiness as reluctance to migrate and commitment to a location - it is like a 'glue' that serves as a counterforce to brain drain. Stickiness is closely intertwined with a location where the individuals are embedded in organisational, social, cultural, emotional and religious contexts. Although individual migratory behaviour takes place in the broader context of national and supranational migration policies and global competition for talent, migratory decisions are made in local contexts (Boccagni \& Baldassar, 2015; Carling, 2013). As we will explain later, these local decisions find application in policies.

\section{A QUALITATIVE CASE STUDY}

This qualitative case study explains why a group of Tanzanian medical doctors decided to stay in their home country instead of migrating, despite very difficult conditions. We will first describe the research setting before detailing data collection and analysis.

\section{Research Setting}

Tanzania is among the 57 countries in the world with a serious deficit in human resources for health (Mills et al., 2011; Sirili et al., 2014; WHO, 2006). Tanzania's health sector is understaffed and characterised by an uneven distribution of health care professionals (Leon \& Riise, 2010) with rural and remote places being the most disadvantaged (Sikika \& MAT, 2013). Tanzania also has one of the lowest levels of highly trained health professionals per capita in the world (Kwesigabo et al., 2012). While Tanzania's ratio of doctors per population was 0.2 physicians per 10,000 people in 2006 (WHO, 2014), the rise was only nominal with 0.5 physicians per 10,000 people in 2011 (MoHSW, 2012).

The shortage of health professionals is further associated with low productivity, ineffective financial and non-financial incentives, poor working conditions, lack of supportive supervision, and poor career schemes, which have caused migration within and outside of Africa (Kaaya et al., 2012). Although this situation is common in all cadres of health professionals, it is particularly serious among medical doctors. As a result, the health care sector in Tanzania is severely hit by brain drain. Most medical doctors have migrated to developed economies in Western Europe and North America, and a significant number to countries in the Southern African Development Community, mainly to the Republic of South Africa, Botswana, Namibia and Lesotho (Tankwanchi, Özden, \& Vermund, 2013).

At the time of data collection in 2008-2009, there was a recruitment freeze in the Tanzanian public sector, and many highly skilled professionals, including medical doctors, who had graduated, were seeking jobs. In 2006, $52 \%$ of Tanzanian doctors were working outside the country (Clemens 
\& Pettersson, 2008), which caused big losses for the country in terms of investments in the education and training of these medical doctors (Mills et al., 2011). Therefore, the few remaining doctors suffered from heavy workload.

Under these extremely severe conditions, the question of why some doctors still decided to stay in Tanzania and contribute to the local community is puzzling. Medical doctors belong to a particularly mobile group of talent (e.g. Adams, 2003), and therefore the group of medical doctors we studied can be regarded as an outlier (Aharoni, 2011). The extreme situation in the entire health care sector in 2008-2009 makes Tanzania a theoretically interesting context to study migration behaviour and provides a setting for developing novel insights (Barnard et al., 2017; Fletcher \& Plakoyiannaki, 2011; Piekkari \& Welch, 2011).

\section{Case Selection}

The group of Tanzanian medical doctors interviewed for the study was identified through several steps. Tanzanian hospitals were first classified in terms of the number and density of medical doctors, their location, the level and status of service provision, and governance. Some private hospitals were excluded due to the envisaged difficulties in negotiating access with the owners. At this stage, four hospitals were identified: two public hospitals (one rural and one urban), a private hospital based in an urban area, and a faith-based hospital located in a rural setting. When comparing the degree of migration across the four hospitals, two hospitals stood out: the public referral hospital in an urban setting, which exhibited high rates of doctor migration, and the faith-based hospital in a rural area, which had managed to retain its medical doctors. The first author negotiated ethical clearance from the Ministry of Health, which paved the way for smooth access to the hospitals.
Table 1 contrasts and compares the two hospitals. We use the pseudonym IMANI (trust in Swahili) for the faith-based, not-for-profit hospital owned by the church. It was located in rural Tanzania with no migration, which is contradictory to the findings in previous studies suggesting that rural hospitals are harder hit by brain drain than urban hospitals (e.g. Serneels et al., 2010). We anonymise the urban hospital as JITEGEMEE (selfreliance in Swahili). It was a government-owned public referral hospital. The two hospitals are also interesting in terms of the ratio between the number of doctors and population catchment. In the JITEGEMEE hospital, the ratio is 300 doctors to 5 million people, and in the IMANI hospital the corresponding number is 11 doctors to 2.4 million people (see Table 1). This raises questions about how the doctors working for the IMANI hospital cope with their workload. When further comparing the two hospitals, we paid special attention to the medical doctors who decided to stay in Tanzania rather than migrate. Since some of these medical doctors worked for the IMANI hospital and others for the JITEGEMEE hospital, we 'sliced' the two hospitals horizontally and cased (Ragin, 1992) this group of doctors in order to better understand their motives not to migrate. Thus, our study is not a comparative case study of two hospitals but a single case study of this particular group of doctors.

\section{Data Collection and Analysis}

The first author conducted 31 face-to-face individual interviews with medical doctors in the two hospitals. This study focuses primarily on the 20 doctors who did not migrate, although we do refer to the eight doctors in the diaspora. ${ }^{5}$ Table 2 shows the distribution of interviewees and their gender across the two hospitals. The small share of female doctors reflects the broader situation in Tanzania. Traditionally, Tanzanian females have been marginalised in terms of access to education. Although

Table 1 Overview of hospitals

\begin{tabular}{lll}
\hline Characteristics & JITEGEMEE hospital & IMANI hospital \\
\hline Year of establishment & 1897 & 1955 \\
Governance & Public (semi-autonomous) & Private (not-for-profit/NGO) \\
Ownership & Government & Church \\
Location & Urban & Rural \\
Number of employees & 2700 & 526 \\
Number of doctors & 300 & 11 \\
Population catchment & 5 million people & 2.4 million people \\
Bed capacity & 1500 & 400 \\
\hline
\end{tabular}


Table 2 Summary of interviewees

\begin{tabular}{|c|c|c|c|c|c|c|}
\hline \multirow[t]{2}{*}{ Category } & \multicolumn{3}{|c|}{ JITEGEMEE hospital } & \multicolumn{3}{|c|}{ IMANI hospital } \\
\hline & Male & Female & Total & Male & Female & Total \\
\hline Non-migrant doctors & 9 & 5 & 14 & 6 & 0 & 6 \\
\hline Doctors in diaspora & 7 & 1 & 8 & 0 & 0 & 0 \\
\hline Hospital director & 0 & 0 & 0 & 1 & 0 & 1 \\
\hline Human resource officers & 1 & 0 & 1 & 1 & 0 & 1 \\
\hline Total & 17 & 6 & 23 & 8 & 0 & 8 \\
\hline
\end{tabular}

Table 3 Overview of additional data sources

\begin{tabular}{|c|c|c|c|}
\hline Data source & JITEGEMEE hospital & IMANI hospital & Ministry of health \\
\hline Documents & $\begin{array}{l}\text { Strategic plans, annual reports, HR } \\
\text { records on recruitment, training, } \\
\text { performance management, rewards, } \\
\text { migration trends, communication } \\
\text { channels (e.g. notice boards), } \\
\text { research reports }\end{array}$ & $\begin{array}{l}\text { Strategic plans, annual reports, } \\
\text { communication channels (e.g. notice } \\
\text { boards), research reports }\end{array}$ & $\begin{array}{l}\text { National HRM policy documents (e.g. } \\
\text { health sector profiles in different time } \\
\text { periods, health sector reform } \\
\text { programme, research reports, public } \\
\text { private partnership policy, staffing } \\
\text { levels of medical specialists, health } \\
\text { crisis in Tanzania) }\end{array}$ \\
\hline Observation & $\begin{array}{l}\text { Patient daily workload (inpatients), } \\
\text { organisation culture (doctors' } \\
\text { morning pre-meetings) }\end{array}$ & $\begin{array}{l}\text { Patient daily workload (inpatients) } \\
\text { organisation culture (e.g. participation } \\
\text { in daily morning prayers) Teamwork } \\
\text { between Tanzanian and expatriate } \\
\text { doctors }\end{array}$ & \\
\hline
\end{tabular}

this trend is changing in the post-independence period, the development is slow, particularly in rural settings where the IMANI hospital is located.

The interviews with medical doctors covered themes such as education, training and employment background, factors that influenced their career choices and specialities, the motivation to work for the respective hospitals and the factors that influenced their continued employment in Tanzania despite the attractiveness of migration. The first author also identified and interviewed eight medical doctors who had left the JITEGEMEE hospital and migrated abroad. The medical doctors interviewed were willing to connect the researcher with their colleagues who had migrated to other countries. The interview questions for the doctors in the diaspora included the same topics as above, but they also covered the decision to migrate from Tanzania and the factors that might attract these doctors to return to their home country.

The first author interviewed the HR directors of the two hospitals and the hospital director of the IMANI hospital in order understand the policies and practices to recruit, train, develop and retain medical doctors. While it would have been insightful to also interview the hospital director for
JITEGEMEE, a strike of medical doctors made it difficult to do so. Furthermore, the first author held discussions with officials in the Ministry of Health during 2008 and 2009 to gain a holistic understanding of the context. All interviews were held in English, but Swahili was used in informal conversations with lower level employees or for seeking clarifications in the hospital environment. The first author does not have medical training; he is an academic at a public university in Tanzania and a consultant in human resource management. To honour the confidentiality agreements with research participants, numbers are used throughout the findings section to denote which doctor is being quoted (e.g. J1 for the first interviewee from the JITEGEMEE hospital and I1 for the first interviewee from the IMANI hospital). We have purposefully used African names as pseudonyms for our participants to remind the reader that the interviews were collected in Tanzania.

In addition to interview data, strategic plans, policy documents, annual reports, HR records on staffing, training and development, career development and rewards were used as supporting material (Maestad \& Brehony, 2007). It is common in case study research to draw on multiple data sources in 
order to investigate the case in its natural context (Piekkari, Welch, \& Paavilainen, 2009). Table 3 provides an overview of the data sources used in the study.

When analysing the rich qualitative material, we first wrote up the study as a comparative case study of the two hospitals. The interview transcripts and other data were read multiple times, coded and categorised into meaningful themes. As the analysis progressed, the medical doctors who had decided to stay in Tanzania caught our attention. Their purpose-driven behaviour was an important insight that guided us to the literature on medical health workers in Africa. In this regard, we followed abductive rather than inductive reasoning in analysing the data (Tavory \& Timmermans, 2014). The study turned into a case of human stickiness among the Tanzanian medical doctors as a counterforce to brain drain.

\section{FINDINGS}

In this section, we present findings from our interviews with the Tanzanian medical doctors working for the IMANI and JITEGEMEE hospitals. We have organised the findings around the doctors' purpose-driven behaviour that stems from family embeddedness, embeddedness in faith communities, embeddedness in the broader society and home country, and knowledge sharing with incoming expatriate doctors.

The IMANI hospital is a faith-based hospital that was established in the northeast of Tanzania in 1955. It plays a substantial role in the provision of health care in Tanzania and serves 2.4 million people in its direct catchment and nearby districts and regions. IMANI is registered as a private hospital and has been part of the Tanzanian central health plan since 1967. It has had a referral status at the regional level since 2010. The hospital has 420 beds and 580 staff and provides care to an average of 16,000 inpatients and 60,000 outpatients yearly.

The JITEGEMEE hospital is a semi-autonomous national referral research centre and a university teaching hospital. It has bed facility for 1500 patients, attending 1000-1200 outpatients per day, and admitting 1000-1200 inpatients per week. It has 3000 employees, of which 300 are medical doctors and specialists, 900 registered and enrolled nurses and the rest are supporting operations employees. The hospital was established in 1897. It provides specialised care to referral cases that require advanced technology and highly educated medical doctors.

\section{Family Embeddedness}

The medical doctors were deeply embedded in relationships with members of the extended family. These relationships were as important as or, in some cases, even more important than the relationships with the spouses and children. Family ties are rooted in African tribal traditions and customs, and they extend beyond conjugal members, thus forming a broad web of relationships. This chain of close and distant relatives creates financial and social obligations for members who have relatively more economic power. In the wake of a nonexistent national social welfare system in Tanzania, the role of the family is accentuated. We use the term 'family' here to broadly refer to any form of blood relationship encompassing very distant and very proximate members, including children, parents (e.g. father, mother), grandparents, aunts, uncles, cousins, and other kinship.

Family members in Africa used to live in close proximity to each other. However, job opportunities have necessitated that family members with employment move to distant locations both within and outside the country, which is accepted and even cherished by other family members. Yet, migration to other countries raises concerns among those members who are left behind. While not all doctors had strong family ties, those who had could only leave the country subject to their parents' and relatives' approval. Aging parents often discouraged their children to migrate in fear of losing close care.

The following quotations reveal how some doctors feared that leaving their dependents behind with no reliable means of support would have negative consequences. Others blamed the close family ties for preventing them from searching alternative employment. Doctor Zawadi, a specialist in internal medicine at the JITEGEMEE hospital, describes many roles and responsibilities in taking care of the extended family which rendered migration an unattainable aspiration:

My father is 72 years old and my mother is 67 years old. My two brothers are not well educated. They only engage in subsistence farming and petty businesses in nearby districts. On the top of that, I also take care of my grandmother whose two sons died in an accident in 2007. When you add up my nuclear family of four people (that is, my husband and I, and our two children), you realise that there are many people I have to take care of. Our culture entails maintaining strong links with other extended families. I am the only educated one on the side of my parents (J7). 
While a migrant doctor can send money to relatives, mistrust among some family members can disrupt the smooth transfer of money to the intended recipient. In this context, Doctor Zawadi adds: "My close presence to my parents rekindles their hope. It gives the parents' safety assurance against whatever problems may arise."

Medical doctors are often seen as those family members who enjoy higher economic and social power than others and who end up becoming bread earners for their families. Doctor Kisoli, a specialist in internal medicine at the JITEGEMEE hospital, commented: "I am the overseer of the welfare of my clan. There is no way I can be tempted to leave (JI4)." In a similar vein, Doctor Halima, a psychiatrist at the JITEGEMEE hospital, affirms the close family bond:

I once got tempted to apply for a job opportunity outside the country. I could however not do so because of family commitment. In the African tradition, we have extended families. I have so many dependents apart from my immediate family. There are many distant relatives who all need our assistance. It becomes difficult to leave these people (J10).

However, some doctors working for the JITEGEMEE hospital did migrate in search of opportunities for improved family welfare. They had concerns about being able to grant a decent education and standard of living for their children and spouses. Doctor Kilimba, a urologist who migrated from the JITEGEMEE hospital to Canada, provides insights into his decision-making:

\begin{abstract}
Salary used to be an issue for my desire to meet the needs of my family. In the wake of active engagement in private practice, I can at least manage my financial obligations. However, I had deep concerns about the deterioration of the education standards. My wife and I will be at peace if our children get a quality education...I was eager to ensure that my children get the opportunity to study in Canada where I believed in high-quality education (J2).
\end{abstract}

Doctor Mwenesi, a former ophthalmologist at the JITEGEMEE hospital, had also migrated, but to the United Kingdom: "My goal when I left Tanzania was to ensure that the children get a better education with high possibilities to acquire specialised training in technological courses of study. I have been able to send my children to good schools (J3)." For highly-skilled professionals, family welfare in terms of education and employment conditions is central. In the Tanzanian culture, a person's success is judged by the quality of the education that his/her children have. Like all parents, doctors also believe that education is the biggest asset parents can give to their children. However, deteriorating standards of education precipitated outmigration. Doctors in diaspora viewed migration as a window of opportunity to ensure family welfare. Taken together, our findings emphasise the importance of family embeddedness in explaining the medical doctors' migratory behaviour.

\section{Embeddedness in Organisational Faith Communities}

As mentioned earlier, IMANI is a faith-based hospital owned by the Evangelical Lutheran Church of Tanzania. The hospital vision caters for the physical, mental, spiritual and social needs of the surrounding community. Unlike many Tanzanian hospitals, the IMANI hospital had managed to retain its medical doctors, and the annual reports provide additional evidence of stable staffing levels. Many of the doctors working at the IMANI hospital expressed moral satisfaction derived from their religious orientation, aligning themselves with the hospital's vision. For example, Doctor Tumaini, a specialist in ophthalmology, had worked for the IMANI hospital for 12 years. He was first employed as a clinical officer and then promoted to assistant medical officer and a medical specialist position following an array of medical courses in Tanzania and abroad. His long tenure at the hospital seems to be closely associated with his religious conviction, which stems from his childhood upbringing. He is the son of a pastor and a follower of the Lutheran Church. He sums up his work motto as follows: "I regard my job as a call for duty rather than just work that I was hired to do". The doctor further attests that "being a Christian, this is where I am serving God" (I5). He views the medical profession as inseparable from his life.

Doctor Bayo, a specialist in internal medicine who had worked at the IMANI hospital for 8 years, was also religious. He describes his role as "providing physical and spiritual services to the patients" (I3). Another specialist in internal medicine at the IMANI hospital, Doctor Kagenzi, underscores the collegial relationships between members of the faith community: "Working with doctors who share a similar faith and cultural orientation...makes us view the high workload as manageable" (I2). This view was also supported by the Director of the IMANI hospital: "Our Christian faith is important to the attainment of the hospital mission" (I1). 
The individual interviews with the doctors working for the IMANI hospital reveal their strong work commitment. In their view, giving treatment to the sick was socially valuable and they worked wholeheartedly in the rural setting despite alternative job opportunities in big cities and even abroad. Their dedication did not seem to be associated with financial gain but rather with an inner calling to serve human beings and, in doing so, to serve God. Their job description covered the provision of both 'physical and spiritual services to the patients' which can be attributed to their Christian values and beliefs. Observational data revealed that doctors and other staff practise morning prayers at the IMANI hospital which further inculcated a sense of purpose of their work.

Our findings suggest that the medical doctors working for the IMANI hospital were deeply embedded in the faith community of the organisation, which increased their moral satisfaction and enhanced their retention rate.

\section{Embeddedness in the Broader Society and Home Country Context}

Some doctors in both the JITEGEMEE and IMANI hospitals cherished their good relationships with members of the broader community in the hospital locality. These relationships developed a sense of belonging to the community and devotion to render health services in the country. For example, Doctor Bahati is an ophthalmologist who has been working at the IMANI hospital for 14 years and who comes from a nearby district. While other doctors prefer to work in hospitals located in towns and big cities, Doctor Bahati is proud to be working in a rural setting.

During the interview, Doctor Bahati tells that the management of the IMANI hospital offered employment to three of his family members: his son in mechanics, his brother-in-law in carpentry, and his sister in nursing. Doctor Bahati is grateful and relieved for these employment opportunities, which mean that his family does not expect him to give more than minimal financial assistance during times of emergency. In rationalising his decision to continue working at the IMANI hospital, the doctor said:

The hospital has supported my postgraduate training in the UK and Norway. I am being valued by management. I do value the way members of my extended family are benefitting by being engaged in the hospital's economic projects. This gives me much relief because it enabled them to be selfreliant and they could manage their livelihood (I4).
A supporting comment is provided by Doctor Masumbuko at the IMANI hospital:

I grew up and got educated in this district. I then started a job here. I have become used to this place. Many people don't like to work in such an environment. I said to myself, "if I do the same, how would these poor villagers get health services?" I could not run away from the problem (I6).

This doctor further notes: "I, for one, value Christian values. I believe that God sent me to work here and serve the people. I wish to serve the Church (I6)." Doctor Kazimoto is a paediatrician who had worked at the JITEGEMEE hospital for twelve years. Despite personal and professional relationships with Tanzanian colleagues in diaspora and professional medical colleagues abroad, he re-affirmed his commitment to stay and work at the JITEGEMEE hospital in Tanzania. This devotion stems from his sense of nationalism to serve his home country. Doctor Kazimoto remarked:

I felt guilty conscious [sic]. The hospital financed my specialisation studies. I could not have managed selffinancing. It is indeed my responsibility to reciprocate by offering health services to the poor people in my country who deserve good health care. I have a big role to play in this hospital as well as Tanzania. I will have done my duty if I render service to the many patients who are referred here. Although I had offers from the Gulf, USA, Western Europe and South Africa, I couldn't go. I believe in the values of rendering services to Tanzanians (J1).

Doctor Kalimasi is a specialist in orthopaedics at the JITEGEMEE hospital. He spent nine years during his undergraduate and postgraduate medical studies in Russia and married a Russian lady. The couple have two sons and one daughter. While some of his Tanzanian colleagues decided to work in Russia after completing their studies, he returned to work at the JITEGEMEE hospital in Tanzania. For his part, he did not see any benefit of continuing to work elsewhere than in his home country, Tanzania. He emphatically notes that he had no regrets of returning to Tanzania with his family. During the interview, he sums up the major reason for coming back home as follows: "East, West, home is best" (J8), reflecting strong feelings of patriotism.

Doctor Mwangaza is a paediatrician at the JITEGEMEE hospital and deeply concerned about the acute shortage of specialists in Tanzania:

The vast majority of patients in Tanzania will not see a physician in their lifetime. When I reflect on this scenario, I can hardly dream of leaving to work elsewhere...I pursued this profession for passion and have over time developed a strong sense of social responsibility to provide for the citizens of my country (J9). 
Doctor Kibwana, a specialist in internal medicine, also expressed patriotic values. He is one of the long-serving specialists at the IMANI hospital and prefers to work in his home country: "Tanzania needs a health professional of my kind to serve patients in a village setting (I3)." Patriotism is also shared by Doctor Bayo, a surgeon at the IMANI hospital, who explains: "When you work in an environment where people value what you do, it inspires you to work much harder. I am motivated by recognition by the community (I4)." Doctor Masumbuko, a gynaecologist at the IMANI hospital, shares the affection for Tanzania: "Literally, if one is having the motive of getting much money, this is not the avenue. I work here for passion. I come from rural areas where health services are still very poor. That kind of life rekindles my commitment to save people's lives in Tanzania (I6)."

The interviews with the doctors from the two hospitals reveal patriotic values and a sense of purpose towards the broader society and home country. In spite of their dedication to stay, these doctors also expressed fears of seeing their career progression slow down and not being able to keep up their professional skills. The scarcity of doctors made it difficult to seize local training opportunities, as Doctor Halima, a psychiatrist at the JITEGEMEE hospital, notes: "Had there not been such acute scarcity in our department, I would have specialised in psychiatry in order to improve the quality of service to the patients" (J2). For other doctors, the fear of career isolation or retardation grew so large that they decided to migrate.

\section{Knowledge Sharing with Incoming Expatriate Doctors}

The two hospitals collaborated with foreign governments and health institutions to bring expatriate doctors on short-term contracts to Tanzania and to mitigate career stagnation. Twinning arrangements offered opportunities for exchange of knowledge and skills as the expatriates worked side-by-side with local doctors. The exchange created opportunities for Tanzanian doctors to gain international experience and foster cross-cultural learning. As Doctor Singano at the JITEGEMEE hospital mentioned: "I am gaining international experience through expatriate doctors in my department" (J4). Incoming expatriate doctors also often served as mentors to local doctors in their area of specialisation. Doctor Magona, a specialist in gynaecology at the JITEGEMEE hospital, who had been working closely with a colleague on a two-year contract from abroad, valued the "mentoring from expatriate doctors" highly (J6). Doctor Zawadi added that "...working with expatriates is like studying abroad because you learn much" (J7).

Doctors at both the JITEGEMEE and IMANI hospitals cherished the collaboration with expatriate doctors. For example, Doctor Singano had been working with a team of expatriates from the United States on a joint research project and the collaboration involved site visits of patients in the region. This project also brought about particular equipment to the department which allowed local doctors to perform operations that had previously been referred to outside the country. Similarly, Doctor Tumaini, an ophthalmologist at the IMANI hospital, attested: "As I work closely with different expatriates, I get a wide range of medical skills" (I5). The local doctors were highly motivated to work with expatriate doctors, as they found the collaboration "stimulating." These partnerships focused on joint medical research and delivery of health care services locally. Overall, the engagement with expatriate doctors contributed to local doctors' competence building and their deep embeddedness in the broader society and home country as a counterforce to migration.

\section{DISCUSSION AND CONCLUSION}

In this section, we discuss how individual-level migratory decisions find application in policy and how these decisions are intertwined with global developments (Cerna, 2016; UNESCO, 2018). We adopt a holistic, multivocal approach to policymaking and propose policy initiatives for different policy actors and layers of policy-making. Taken together, these initiatives foster medical doctors' human stickiness in Tanzania and render migration a less attractive career option. They capitalise on the medical doctors' purpose-driven behaviour in order to retain talent locally. Table 4 provides an overview of the national, regional and supranational policy actors and the recommended initiatives.

\section{Initiatives for National Policy Actors to Capitalise on Medical Doctors' Family Embeddedness, Purpose-Driven Behaviour and Human Stickiness}

As Table 4 shows, the first layer consists of national policies to be considered and formulated by local governments and municipalities, ministries and health sector organisations in the sending country. They are targeted at medical doctors' deep family 
Table 4 Types of policy actors and recommended policy initiatives

National policy actors

National policy actors in sending country

Health sector organisations and professional associations (e.g. Medical Association of Tanzania)

Decision-makers in local governments and municipalities responsible for health care, education and taxation issues

National health ministries, national development ministries, policy experts and politicians

National policy actors in receiving country Health sector recruiting agencies, professional associations and trade unions

Decision-makers in local governments and municipalities responsible for health care, education and taxation issues

National health ministries, national development ministries, policy experts and politicians
Recommended policy initiatives

- Encouragement of spousal and family appointments and traineeship at hospitals where doctors themselves are employed - Digital skill development and knowledge transfer

- Fostering of continued professional development through annual scientific conferences on key public health issues

- Liaison with and advise the government on health and medical matters

- To ensure, maintain and safeguard the interests, privileges and welfare of medical doctors

- Care and health-related benefits to enhance the well-being of doctors' families, including elderly parents

- Social recognition (grants, awards) of doctors' altruistic behaviour in serving the broader community, societal engagement and voluntary work

- Scholarships for the education of doctors' spouses and children

- Settlement support systems for mixed marriage families and transnational families

- Specific tax reliefs for (incl. multi-generational) diaspora returnees to indirectly sponsor local engagement

- Welfare services including housing, utilities and infrastructural development

- A system for reporting medical doctors' and hospitals' concerns on policies and recruiting practices anonymously

- Mapping of current and future medical capacity

- Planning of health care in rural areas and incentives for "centres of excellence"

- Tax benefits for long-term development projects in health sector

- Economic and career incentives through special tax and income benefits for doctors and their family members

- Improvement of infrastructure and digitalisation

- Expansion of education, training and development programmes for women in medicine to mitigate a gender gap

- Encouragement of spousal and family appointments and traineeship at hospitals building skills for potential return and return programmes

- Digital skill development and knowledge transfer

- Development of projects targeted at social and institutional remittances

- Protection and sustainable HR policies for return

- Research cooperation programmes with sending country when applicable

- Scholarships for the education of doctors' spouses and children linked to sending country application

- Specific tax relief programmes to sponsor transnational-local engagement of returnees for capacity building

- Health-tech start-up programmes for those returning to a developing context

- Screening of the effects of international HR practices on triple bottom line and social sustainability in the sending country

- Improvement of infrastructure and digitalisation through coprogrammes, e.g. centres of excellence

- International expansion of education, training and development programmes for women in medicine to mitigate gender gap 
Table 4 (Continued)

National policy actors Recommended policy initiatives

Regional and international policy actors (both sending and receiving countries)

Central and East African governance/African Union, diplomats and experts in EU-Africa dialogue

International Migration Policy Institute, think tanks

International non-governmental organisations

Supranational, multilateral policy actors

WHO, IOM and ILO, OECD, UNCTAD, UN, UNESCO, The World Bank Group and International Development Association
- Intra-African educational exchanges for doctors and their familymembers to enhance targeted capacity building and retention

- Formulation of well-aligned transnational and digital work models andexchange policies for both African and foreign medical doctors

- Attracting and providing scholarships to diaspora returnees to fosterentrepreneurship in health care sector, home country altruism andopportunity co-creation

- Development of continuous training and professional development fordoctors through two-way international mobility scholarships andtwinning arrangements

- Formulation of an incentivising return policy that can unleash the potential of circular migration

- Policy commenting and collection of evidence concerning unsound practices, exploitation and illicit employment in sending and receiving countries

- Orchestration and coordination of migration and globalisation policies to combat structural unsustainable resource exploitation (see 17 UN SDGs)

- Mapping of best practices

- Providing training locally together with externally funded incoming expatriates

- Programmes for funding medical doctors' research projects in Africa

- Funding for medical resources (including centres of excellence) in rural and disadvantaged areas and support to doctors who move into these locations (e.g. taxes, mobility costs, sponsoring, social investments) embeddedness to support the education of medical doctors' children, spousal appointments and recruitment of other family members, as well as to address the care of their elderly parents. These policies enhance local commitment, stickiness, and equality through empowerment and medical education of females, who are less mobile than their male counterparts (Tjadens et al., 2013).

Health organisations, professional associations and municipalities in the sending country need to revise and differentiate national policies to align with medical doctors' sense of purpose and motivate them to stay and contribute locally. These policies may provide tax reliefs and incentives for skill development, but also social acknowledgements of altruistic behaviour in serving the broader community. For example, grants and awards may serve as effective stick factors (see Table 4). Our findings show that the purpose-driven behaviour of
Tanzanian medical doctors had altruistic characteristics, which differs from a post-migratory attitude acknowledged in previous research. Local talent that demonstrates altruistic, purpose-driven behaviour constitutes a contribution to capacity-building in a developing country context (e.g. Brinkerhoff, 2009). Furthermore, family members, patients and colleagues as well as the broader local community are important beneficiaries of altruistic behaviour, calling for targeted, concerted policies. If sufficiently attractive, such policies may also influence doctors in diaspora to return to or invest in their home country (UNESCO, 2018). Thus, altruism and human stickiness are intertwined forces that offer a novel lens for designing actionable policies.

National institutions in receiving countries should also act responsibly and develop mutual programmes that strengthen local communities in 
sending countries as part of their sustainability policy, as Table 4 suggests. Professional associations representing the health sector, ministries and municipalities need to join forces internationally to foster knowledge and competence development locally. National institutions especially need to deal with contextual impediments that hinder local commitment to capacity building, such as lack of public-private investment, corruption and mismanagement of local human resources, and connect to the global competition on talent.

\section{Initiatives for Supranational Policy Actors to Enhance Local Capacity-Building}

As Table 4 shows, another layer of policies is shaped in cooperation with supranational and international organisations. In particular, these policies aim at facilitating capacity-building through multidirectional exchange and incoming flows of expatriate doctors through, e.g., twinning arrangements. Building local capacity in Tanzania should take place through a concerted effort between different layers of policies and policymakers, i.e. capacity-building is inherently about co-creation. The quality of skills and competences among local medical doctors is crucial for the Tanzanian society, the viability of its medical system and the basis for sustainable mobility circulation. Our findings suggest that a key to retaining medical doctors in Tanzania is their continuous professional development, which is partly linked to foreign programmes and support (Moullan, 2013). Yet, this goal is challenging to achieve due to the extreme conditions in Tanzania, especially in rural settings. Thus, purpose-driven behaviour, which is highly context-specific and reflects the local cultural and religious environment, calls for better understanding of the role of faith in management and governance (see also Barnard et al., 2017).

The purpose-driven behaviour that we identified offers an opportunity to revise supranational policy-making, because medical doctors are an integral part of the global workforce and sustainable local capacity-building (see Table 4). Multidirectional exchange programmes, especially when positively motivated through religion and altruism, fill a void caused by regulatory deficiencies of human resource governance and unequal migration policies. Hence, inter-governmentally agreed, wellaligned transnational work models and exchange policies for both intra-African and incoming expatriate doctors can increase local capacity-building through talent retention, interaction and social remittances, and produce positive brain circulation (Tung, 2008).

Since even a small increase in foreign health assistance leads to substantial retention of medical professionals (Moullan, 2018), we propose targeted assistance and funding programmes that connect supranational and municipal levels through, e.g., centres of excellence. Competitive professional development (e.g. knowledge sharing, collaborative work and research) in Tanzania reduces the need to migrate for skill development (see Moullan, 2013). Tanzanian doctors also benefit from short-term professional exchange abroad as an alternative to permanent migration. This multidirectional flow of experts is a powerful means to develop professional competence locally and cultivate long-term benefits of circular migration. Thus, both sending and receiving countries' policies are intertwined with bi- and multilateral policy-making.

The interplay between incoming and outgoing medical expertise can become a form of triangular human resource flow and triple win (DeVoretz \& Ma, 2002; Tung, 2008). This dynamic interplay between two separate flows of migration - outmigration of Tanzanian doctors and circular migration of expatriate doctors - introduces a new helixlike layer to the triangle of circular migration that requires the attention of international policy actors (e.g. DeVoretz \& Ma, 2002; see also Brinkerhoff, 2016, on in-between advantage). Currently, the lack of an incentivising return policy makes it difficult to reap the benefits of circular migration (Minto-Coy \& Elo, 2017) and remittances (McCormick \& Wahba, 2000; Ratha \& Mohapatra, 2013). Medical doctors' mobility programmes call for differentiated orchestration of capacity-building that is targeted at vulnerable contexts. Short-term mobility programmes can be very beneficial to enhance human stickiness of Tanzanian doctors, reduce brain drain and increase the degree of circularity (Zimmermann, 1996). Regional and international policy actors could develop joint policies for exploiting the potential of triple win in Central and East Africa and in the EU-Africa dialogue. Supranational multilateral organisations, such as the UN, IOM, WHO, and OECD, need to evaluate and revise malfunctioning policies that cause inequality and are challenging to implement.

\section{Avenues for Future Research}

Today, career mobility of highly-skilled professionals in the form of outmigration has become the new 
normal (Brewster, 2004; Guo \& Al Ariss, 2015) in developing countries, especially in rural areas, creating a 'demographic time bomb' (Tjadens et al., 2013: 16). Future research should address the normalisation of mobility by focusing on the interplay between human resource policies and national and international migration policies (Tjadens et al., 2013). Inadequate resources for training, intramural private practices, and impediments on recruitment mean that human resource departments in Tanzania have limited tools to retain talent or foster talent circulation.

The faith-based rural hospital IMANI was an exception. It was able to retain its highly-skilled medical doctors because it capitalised on their sense of purpose. The hospital management fostered the well-being of medical doctors' families and responded to their needs to serve the broader community and country. Medical doctors working for this faith-based hospital had a collective, shared sense of purpose (e.g. Anderson et al., 2018). The HR policies and practices contributed to the doctors' job satisfaction and contentment. In contrast, the non-faith-based hospital was not able to reach similar levels of talent retention, suggesting that the effect of purpose may be stronger in a supportive and inclusive environment.

Recent advances in telemedicine make it possible for doctors to provide medical counselling without physical presence. This allows also doctors - regardless of their location - to help patients through virtual presence. In this regard, technological advances challenge the traditional categories of doctors in the diaspora versus non-migrant doctors. Future research could shed light on the potential of digital skill development and knowledge transfer for capacity-building in developing countries (see Table 4).

Our findings initiate a conversation about how policy actors can better employ purpose-driven behaviour in formulating new non-economic policies and incentives and lead processes that enhance human stickiness locally. We call for holistic, multilevel research on the mobility of highlyskilled professionals in developing countries that pays attention to the length and return options that these professionals have, as well as their diverse career paths, families and life courses (Adésinà, 2007). Policies regulating talent mobility have typically not paid much attention to mixed families, multigenerational diaspora and dual citizenship. We believe future research should include them and also explicitly incorporate the viewpoints of highly-skilled professionals' families and incoming expatriate doctors to better harness the potential of knowledge sharing. Existing policies and programmes are far from adequately implemented and we need innovative solutions to remove institutional bottlenecks that hamper medical doctors' careers.

\section{FINAL REMARKS}

Recently, migration has gained attention due to remittances that represent a larger financial flow than foreign direct investment, particularly in developing countries, but also due to the positive effects of transnational business, diaspora engagement and returnee investments across the world (e.g. Elo \& Minto-Coy, 2018; Nkongolo-Bakenda \& Chrysostome, 2013; Vaaler, 2011, 2013; Wescott \& Brinkerhoff, 2006). This study contributed to migration research in international business by offering purpose-driven behaviour as a novel explanation of non-migration decisions and by connecting local and global human talent flows in a dynamic way. Prior research has largely addressed migration as a form of human talent flow (i.e. brain drain) that affects national competitiveness (e.g. Tung, 2008), or as part of globalisation and economic development, also producing global inequality (e.g. Castles, 2009). So far, debates on nonmigration have been scarce. Yet, stickiness and stick factors are promising aspects to consider when formulating policies to combat exploitative drivers (Moullan, 2018; Tjadens et al., 2013). We found that purpose-driven behaviour among highlyskilled professionals can serve as a counterforce to brain drain, increasing stickiness of human talent and local capacity-building. This resonates well with the findings of the World Happiness Report (Helliwell, Layard, \& Sachs, 2013), suggesting that access to income is one of the human choices, but it is not the total sum of human endeavour. Thus, it leaves considerable scope for policy-making (Tjadens et al., 2013).

Tanzania represented an extreme context of talent shortage and a laboratory for novel theoretical insight (Barnard et al., 2017). Such extreme conditions lay open the urgent need to coordinate migration policy on a global level in line with the sustainable development goals set by the UN. Integrated migration and talent policies bring together the perspectives of policy actors on municipal, industry, national, regional and supranational levels in order to reach the goals set for 
ethical and sustainable global migration (Adams, 2003; Hilderbrand et al., 1997). Globally coordinated policies allow for the co-development of career paths of highly-skilled professionals, knowledge sharing, family integration and educational programmes that reduce the gap between developing and developed economies. We believe that new digital, flexible and global work models have the potential to engage with both a sense of purpose and development to combat global inequality (Tung, 2008; Zimmermann, 1996).

To conclude, we argue that international organisations (e.g. UN, IOM, The World Bank Group) should use their position to tackle development asymmetries, inequality, and unsustainable migration policies between the Global South and the Global North. If the overall system distorts global flows of people, then a single hospital or nation state has very limited ability to turn around those dynamics.

\section{ACKNOWLEDGEMENT}

The first author would like to thank Mzumbe University Management for the financial support and study leave, and Professor Emeritus Harald Knudsen and Professor Roy Mersland for their invaluable guidance, inspiration and support during the research process. The second author would like to acknowledge Professor Martin Hannibal's supportive role in writing this paper. We are also very grateful to Professor Elie Chrysostome and the participants in the Cedimes

\section{REFERENCES}

Adams, R. H., Jr. 2003. International migration, remittances, and the brain drain: A study of 24 labor exporting countries (English). Policy, Research working paper series; No. WPS 3069. Washington, DC: World Bank.

Adésinà, J. (Ed.). 2007. Social policy in Sub-Saharan African context: In search of inclusive development. London: Palgrave Macmillan.

Aharoni, Y. 2011. Fifty years of case research in international business: The power of outliers and black swans. In R. Piekkari \& C. Welch (Eds), Rethinking the case study in international business and management research: 41-54. Cheltenham: Edward Elgar.

Akintola, O. 2010. What motivates people to volunteer? The case of volunteer AIDS caregivers in faith-based organizations in KwaZulu-Natal, South Africa. Health Policy and Planning, 26(1): 53-62.

Alleyne, D., \& Solan, I. 2019. Leveraging the Caribbean diaspora for development: The role of network effects. In M. Elo \& I. Minto-Coy (Eds), Diaspora networks in international business: 55-77. Cham: Springer.

Anderson, G., Quinn, R., \& Thakor, A. 2018. Turning purpose into performance. Harvard Business Review, July/August. conference in Plattsburgh, USA (August 30-September 1, 2019), for their encouraging feedback. Finally, we would like to thank Professor Helena Barnard for her outstanding editorial guidance and the anonymous reviewer for very insightful and helpful comments during the review process.

\section{NOTES}

${ }^{1}$ For simplicity, we use the term 'migration' to discuss both international and rural-urban migration, as they are partly intertwined in the African context.

${ }^{2}$ National migration policies may attract certain types of migrants due to political and labour market needs, while attempting to discourage the 'wrong' type of migration through impediments to entry.

${ }^{3}$ Selective approaches concern work-based national in-migration, e.g. Canada's point system. Migration of asylum seekers and refugees is in turn subject to multilateral agreements by the United Nations (Refugee Convention, 1951).

${ }^{4}$ This paper addresses stickiness towards the home country and hence refers to 'staying' by non-migrants in the pre-migratory stage (cf. Tjadens et al., 2013: 35).

${ }^{5}$ Diaspora here refers to doctors abroad who share elements of dispersion, homeland orientation and boundary maintenance (see, Cohen, 2008: 12).

Bakewell, O. 2010. Some reflections on structure and agency in migration theory. Journal of Ethnic and Migration Studies, 36(10): 1689-1708.

Barnard, H., Cuervo-Cazurra, A., \& Manning, S. 2017. Africa business research as a laboratory for theory-building: Extreme conditions, new phenomena, and alternative paradigms of social relationships. Management and Organization Review, 13(3): 467-495.

Barnard, H., \& Pendock, C. 2013. To share or not to share: The role of affect in knowledge sharing by individuals in a diaspora. Journal of International Management, 19(1): 47-65.

Baumgarten, M. 2013. Integrating success, merging individual goals with organizational purpose to enhance perceived levels of happiness and performance. PhD Dissertation, Fielding Graduate University, Ann Arbor, MI.

Beechler, S., \& Woodward, I. C. 2009. The global 'war for talent'. Journal of International Management, 15(3): 273-285.

Beine, M., Docquier, F., \& Rapoport, H. 2008. Brain drain and human capital formation in developing countries: Winners and losers. The Economic Journal, 118(528): 631-652.

Boccagni, P., \& Baldassar, L. 2015. Emotions on the move: Mapping the emergent field of emotion and migration. Emotion, Space and Society, 16: 73-80. 
Brewster, C. 2004. European perspectives on human resource management. Human Resource Management Review, 14(44): 365-382.

Brinkerhoff, J. M. 2009. Digital diasporas: Identity and transnational engagement. Cambridge: Cambridge University Press.

Brinkerhoff, J. M. 2016. Institutional reform and diaspora entrepreneurs: The in-between advantage. New York: Oxford University Press.

Carling, J. 2013. Ensuring the welfare of children who stay when parents migrate. PRIO Policy Brief, 8. Oslo: Peace Research Institute Oslo (PRIO).

Carling, J., \& Collins, F. 2018. Aspiration, desire and drivers of migration. Journal of Ethnic and Migration Studies, 44(6): 909926.

Carling, J., \& Schewel, K. 2018. Revisiting aspiration and ability in international migration. Journal of Ethnic and Migration Studies, 44(6): 945-963.

Castles, S. 2009. Development and migration-migration and development: What comes first? Global perspective and African experiences. Theoria, 56(121): 1-31.

Castles, S., De Haas, H., \& Miller, M. J. 2013. The age of migration: International population movements in the modern world. London: Macmillan.

Cerdin, J. L., Diné, M. A., \& Brewster, C., 2014. Qualified immigrants' success: Exploring the motivation to migrate and to integrate. Journal of International Business Studies, 45(2): $151-168$

Cerna, L. 2016. The crisis as an opportunity for change? Highskilled immigration policies across Europe. Journal of Ethnic and Migration Studies, 42(10): 1610-1630.

Clemens, M. A., \& Pettersson, G., 2008. New data on African health professionals abroad. Human Resources for Health, 6(1): 1.

Cohen, R. 2008. Global diasporas: An introduction, 2nd ed. Oxford: Routledge.

Csikszentmihalyi, M. 2004. Good business: Leadership, flow, and the making of meaning. New York: Penguin.

Czaika, M. (Ed.). 2018. High-skilled migration: Drivers and policies. Oxford: Oxford University Press.

De Haas, H. 2010. Migration and development: A theoretical perspective. International Migration Review, 44(1): 227-264.

DeVoretz, D. J., \& Ma, J. 2002. Triangular human capital flows between sending, entrepot and the rest of the world regions. Canadian Studies in Population, 29(1): 53-69.

Dorigo, G., \& Tobler, W. 1983. Push-pull migration laws. Annals of the Association of American Geographers, 73(1): 1-17.

Elo, M. 2016. Typology of diaspora entrepreneurship: Case studies in Uzbekistan. Journal of International Entrepreneurship, 14(1): 121-155.

Elo, M., \& Minto-Coy, I. 2018. Diaspora networks in international business. Cham: Springer.

Elo, M., \& Riddle, L. (Eds). 2016. Diaspora business. Oxford: Inter-Disciplinary Press.

Elo, M., \& Vemuri, S. 2016. Organizing mobility: A case study of Bukharian Jewish diaspora. Diaspora Studies, 9(2): 179-193.

Emmanuel, D. N. 2018. The role of human resource management practices in the migration of medical doctors in developing countries: The case of Tanzania. Unpublished PhD Dissertation, School of Business and Law, University of Agder.

Fletcher, M., \& Plakoyiannaki, E. 2011. Case selection in international business: Key issues and common misconceptions. In R. Piekkari \& C. Welch (Eds), Rethinking the case study in international business and management research: 171-192. Cheltenham: Edward Elgar.

Glick Schiller, N., \& Salazar, N. B. 2013. Regimes of mobility across the globe. Journal of Ethnic and Migration Studies, 39(2): 183-200.

Guo, C., \& Al Ariss, A. 2015. Human resource management of international migrants: Current theories and future research. The International Journal of Human Resource Management, 26(10): 1287-1297.
Habti, D., \& Elo, M. (Eds). 2018. Global mobility of highly skilled people. Multidisciplinary perspectives on self-expatriation, Vol. 16. Cham: Springer.

Hagopian, A., Thompson, M. J., Fordyce, M., Johnson, K. E., \& Hart, L. G. 2004. The migration of physicians from subSaharan Africa to the United States of America: Measures of the African brain drain. Human Resources for Health, 2(1): 17.

Hatton, T. J., \& Williamson, J. G. 2005. Global migration and the world economy: Two centuries of policy and performance. Cambridge, MA: MIT Press.

Helliwell, J. F., Layard, R., \& Sachs, J. (Eds). 2013. World happiness report 2013. New York: UN Sustainable Development Solutions Network.

Hilderbrand, M. E., Grindle, M. S., Trostle, J. A., Sommerfeld, J. U., Simon, J. L., Lippincott III, D. F., \& Contreras, M. E. 1997. Getting good government: Capacity building in the public sectors of developing countries. Cambridge, MA: Harvard University Press.

Jackson, L. E., \& Coursey, R. D. 1988. The relationship of God control and internal locus of control to intrinsic religious motivation, coping and purpose in life. Journal for the Scientific Study of Religion, 27(3): 399-410.

Kaaya, E. E., Macfarlane, S. B., Mkony, C. A., Lyamuya, E. F., Loeser, H., et al. 2012. Educating enough competent health professionals: Advancing educational innovation at Muhimbili University of Health and Allied Sciences, Tanzania. PLoS Med, 9(8): e1001284.

Kashdan, T., \& McKnight, P. E. 2009. Origins of purpose in life: Refining our understanding of a life well lived. Psychological Topics, 18(2): 303-316.

Kultalahti, O., Karppi, I., \& Rantala, H. (Eds). 2006. Europe in flux: Transitions and migration pressures. Turku: Institute of Migration.

Kwesigabo, G., Mwangu, M. A., Kakoko, D. C., Warriner, I. Mkony, C. A., et al. 2012. Tanzania's health system and workforce crisis. Journal of Public Health Policy, 33(S1): S35S44.

Lee, E. S. 1966. A theory of migration. Demography, 3(1): 4757.

Leon, B., \& Riise, J. 2010. Wrong schools or wrong students? The potential role of medical education in regional imbalances of the health workforce in the United Republic of Tanzania. Human Resources for Health, 8:3.

Lerner, J. S., Li, Y., Valdesolo, P., \& Kassam, K. S. 2015. Emotion and decision making. Annual Review of Psychology, 66: 799823.

Leshabari, M. T., Muhondwa, E. P., Mwangu, M. A., \& Mbembati, N. A. 2008. Motivation of health care workers in Tanzania: A case study of Muhimbili National Hospital. East African Journal of Public Health, 5(1): 32-37.

Maestad, O., \& Brehony, E. 2007. Review of Haydom Lutheran Hospital. CMI Report, 18: 1-44.

Marchal, B., \& Kegels, G. 2003. Health workforce imbalances in times of globalization: Brain drain or professional mobility? The International Journal of Health Planning and Management, 18(S1): S89-S101.

Mbindyo, P., Gilson, L., Blaauw, D., \& English, M. 2009. Contextual influences on health worker motivation in district hospitals in Kenya. Implementation Science, 4(1): 43.

McCormick, B., \& Wahba, J. 2000. Overseas employment and remittances to a dual economy. The Economic Journal, 110(463): 509-534.

Mills, E. J., Kanters, S., Hagopian, A., Bansback, N., Nachega, J., et al. 2011. The financial cost of doctors emigrating from subSaharan Africa: Human capital analysis. BMI, 343:d7031.

Minto-Coy, I. D., \& Elo, M. 2017. Towards an entrepreneurial ecosystem for diaspora engagement. Mona School of Business and Management Business Review, 3(4): 29-30.

MoHSW. 2012. The health sector performance profile 2011. Daar es Salaam: MOHSW. 
Moullan, Y. 2013. Can health foreign assistance break the medical brain drain? Journal of Development Studies, 49(10): 1436-1452.

Moullan, Y. 2018. What fundamentals drive the immigration of physicians? A panel data analysis of OECD Countries. In M. Czaika (Ed.), High-skilled migration: Drivers and policies: Ch. 14, 1-27. Oxford: University Press, Oxford Scholarship Online.

Nielsen, T. M., \& Riddle, L. 2009. Investing in peace: The motivational dynamics of diaspora investment in post-conflict economies. Journal of Business Ethics, 89(4): 435-448.

Nkongolo-Bakenda, J. M., \& Chrysostome, E. V. 2013. Engaging diasporas as international entrepreneurs in developing countries: In search of determinants. Journal of International Entrepreneurship, 11(1): 30-64.

OECD. 2015. International migration outlook 2015. Paris: OECD Publishing. https://doi.org/10.1787/migr outlook-2015-en. Accessed 7 February 2019.

Ojo, S. 2015. African Pentecostalism as entrepreneurial space. Journal of Enterprising Communities: People and Places in the Global Economy, 9(3): 233-252.

Otrachshenko, V., \& Popova, O., 2014. Life (dis)satisfaction and the intention to migrate: Evidence from Central and Eastern Europe. The lournal of Socio-Economics, 48(C): 40-49.

Peters, D. H., Chakraborty, S., Mahapatra, P., \& Steinhardt, L. 2010. Job satisfaction and motivation of health workers in public and private sectors: Cross-sectional analysis from two Indian states. Human Resources for Health, 8(1): 27.

Piekkari, R., \& Welch, C. (Eds). 2011. Rethinking the case study in international business and management research. Cheltenham: Edward Elgar.

Piekkari, R., Welch, C., \& Paavilainen, E. 2009. The case study as disciplinary convention: Evidence from international business journals. Organizational Research Methods, 12(3): 567-589.

Radcliffe-Brown, A. R., \& Forde, D. (Eds). 2015. African systems of kinship and marriage. Oxford: Routledge.

Ragin, C. C. 1992. "Casing" and the process of social inquiry. In C. C. Ragin \& H. S. Becker (Eds), What is a case? Exploring the foundations of social inquiry: 217-226. Cambridge: Cambridge University Press.

Ratha, D., \& Mohapatra, S. 2013. Migrant remittances and development. In G. Caprio, T. Beck, S. Claessens, \& S. Schmukler (Eds), The evidence and impact of financial globalization: 121-130. San Diego: Academic.

Refugee Convention. 1951. 2. Convention Relating to the Status of Refugees, Geneva, 28 July 1951, UN General Assembly, United Nations, Treaty Series, Vol. 189, 137. https://treaties. un.org/doc/Treaties/1954/04/19540422\%2000-23\%20AM/ Ch_V_2p.pdf. Accessed 8 July 2019.

Riddle, L., \& Brinkerhoff, J. 2011. Diaspora entrepreneurs as institutional change agents: The case of Thamel.com. International Business Review, 20(6): 670-680.

Schewel, K. 2015. Understanding the aspiration to stay: A case study of young adults in Senegal. IMI Working Papers Series 2015, Vol. 107. International Migration Institute, University of Oxford.

Serneels, P., Montalvo, J. G., Pettersson, G., Lievens, T., Butera, J. D., \& Kidanu, A. 2010. Who wants to work in a rural health post? The role of intrinsic motivation, rural background and faith-based institutions in Ethiopia and Rwanda. Bulletin of the World Health Organization, 88: 342-349.

Siddiqui, Z., \& Tejada, G. 2014. Development and highly skilled migrants: Perspectives from the Indian diaspora and returnees. International Development Policy/Revue Internationale de Politique de Développement, 5.2.

Sikika \& MAT (The Medical Association of Tanzania). 2013. Where are the doctors? Tracking study of medical doctors. Dar es Salaam: Jamana.

Sirili, N., Kiwara, A., Nyongole, O., Frumence, G., Semakafu, A., \& Hurtig, A.-K. 2014. Addressing the human resource for health crisis in Tanzania: The lost in transition syndrome. Tanzania Journal of Health Research, 16(2): 104-111.

Spencer, J. H. 2004. People, places, and policy: A politically relevant framework for efforts to reduce concentrated poverty. Policy Studies Journal, 32(4): 545-568.

Spencer, S. 2011. The migration debate. Bristol: Policy Press.

Spencer, S., \& Charsley, K. 2016. Conceptualising integration: A framework for empirical research, taking marriage migration as a case study. Comparative Migration Studies, 4(1): 18.

Stahl, G., Miller, E., \& Tung, R. 2002. Toward the boundaryless career: A closer look at the expatriate career concept and the perceived implications of an international assignment, Journal of World Business, 37(3): 216-227.

Tankwanchi, A. B. S., Ozden, C., \& Vermund, S. H. 2013. Physician emigration from sub-Saharan Africa to the United States: Analysis of the 2011 AMA physician masterfile. PLoS Med, 10(9): e1001513.

Tavory, I., \&Timmermans, S. 2014. Abductive analysis: Theorizing qualitative research. Chicago: University of Chicago Press.

Tjadens, F., Weilandt, C., \& Eckert, J. 2013. Mobility of health professionals, health systems, work conditions, patterns of health workers' mobility and implications for policy makers. Cham: Springer.

Tung, R. L. 2008. Brain circulation, diaspora, and international competitiveness. European Management Journal, 26(5): 298304.

UNESCO. 2018. African brain drain: Is there an alternative? The Unesco Courier January-March. https://en.unesco.org/courier/ 2018-1/african-brain-drain-there-alternative. Accessed 13 June 2019.

Vaaler, P. M. 2011. Immigrant remittances and the venture investment environment of developing countries. Journal of International Business Studies, 42(9): 1121-1149.

Vaaler, P. M. 2013. Diaspora concentration and the venture investment impact of remittances. Journal of International Management, 19(1): 26-46.

Van Hear, N., Bakewell, O., \& Long, K. 2018. Push-pull plus: Reconsidering the drivers of migration. Journal of Ethnic and Migration Studies, 44(6): 927-944.

Wescott, C. G., \& Brinkerhoff, I. M. (Eds). 2006. Converting migration drains into gains: Harnessing the resources of overseas professionals. Manila: Asian Development Bank.

WHO. 2006. The world health report 2006: Working together for health. Geneva: World Health Organization.

WHO. 2014. Health workforce density of physicians. Geneva: World Health Organization.

Wrzesniewski, A., McCauley, C., Rozin, P. \& Schwartz, B. 1997. Jobs, careers, and callings: People's relations to their work. Journal of Research in Personality, 31(1): 21-33.

Zimmermann, K. F. 1996. European migration: Push and pull. International Regional Science Review, 19(1-2): 95-128.

\section{ABOUT THE AUTHORS}

Ndikumana David Emmanuel is Senior Lecturer of International Human Resource Management at Mzumbe University, School of Public Administration and Management in Tanzania. His research focuses on migration of skilled professionals, unlocking the potential of diaspora, cross-cultural management and knowledge transfer in developing countries as well as the applicability of Western management theories in developing countries. 
Maria Elo is Associate Professor at the University of Southern Denmark, BRIIB Professor of International Business at Belt and Road Institute of International Business, Shanghai University. She researches transnational/diaspora business and entrepreneurship, migration, global mobility, and internationalisation. She has published in diverse journals such as Industrial Marketing Management, Journal of International Management, Regional Studies, International Journal of Entrepreneurship and Small Business.

Rebecca Piekkari is Professor of International Business at Aalto University, School of Business. Her research focuses on the challenges of managing multinational and multilingual corporations and the use of qualitative methods in international business research. Her work has been published in journals such as the Academy of Management Review, the Journal of International Business Studies as well as several handbooks in the area.

Open Access This article is distributed under the terms of the Creative Commons Attribution 4.0 International License (http://creativecommons. org/licenses/by/4.0/), which permits unrestricted use, distribution, and reproduction in any medium, provided you give appropriate credit to the original author(s) and the source, provide a link to the Creative Commons license, and indicate if changes were made.

Publisher's Note Springer Nature remains neutral with regard to jurisdictional claims in published maps and institutional affiliations.

Accepted by Helena Barnard, Area Editor, 30 August 2019. This article has been with the authors for two revisions. 